\begin{tabular}{|lll|}
\hline & Uniqbu Journal of Social Sciences (UJSS) \\
\hline Volume: 2 & Nomor 1, April 2021 Halaman 87-94 \\
\hline
\end{tabular}

\title{
LANGUAGE STYLE IN NOVEL PIANO IN A GLASS BOX BY AGNES JESSICA
}

\section{(Gaya Bahasa pada Novel Piano dalam Kotak Kaca Karya Agnes Jessica)}

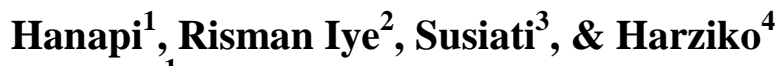 \\ ${ }^{1}$ English Literature Study \\ ${ }^{234}$ Indonesian Literature Study Program, Faculty of Letters \\ Email: hanapiuniqbu@gmail.com \\ rismaniye@gmail.com \\ susiatiuniqbu@gmail.com \\ harziko91@gmail.com
}

(Received 12 February; Revised 28 February; Accepted 03 March 2021)

\begin{abstract}
Literature is a branch of art. About society, literature is a mirror of life that can take advantage of the values that exist in society. This study aims to describe the Language Style in the Piano Novel in Agnes Jessica's Glass Box. The method in this research is descriptive qualitative. Qualitative research is carried out by not prioritizing numbers, but prioritizing the depth of appreciation of the interaction between the concepts being studied empirically in this novel, providing an understanding of course in analyzing literary works with the approach used is a pragmatic approach considering the implications of readers through their various competencies. By considering indicators of literary works and readers, the problems that can be solved through a pragmatic approach, including the various responses of certain communities to a literary work, either as an explicit or implicit reader, both in a synchronic and diachronic framework. The results showed that the language style in the novel Piano in the Glass Box by Agnes Jessica is very varied and creative. Agnes Jessicas' novel Piano in a Glass Box totals 377 pages. The total frequency of using Language Styles is 98 units. In this novel Piano di Kotak Kaca by Agnes Jessicain, there are four groups of language styles, namely comparative language styles, namely parable, metaphor, personification, and antithesis, contradictory language styles, namely hyperbole, litotes, irony, oxymoron, and zeugma.
\end{abstract}

Keywords: Language Style, Glass Box,

\begin{abstract}
Abstrak
Sastra adalah salah satu cabang seni. Tentang masyarakat, sastra merupakan cermin kehidupan yang dapat memanfaatkan nilai-nilai yang ada di masyarakat. Penelitian ini bertujuan untuk mendeskripsikan Gaya Bahasa dalam Novel Piano dalam Kotak Kaca karya Agnes Jessica. Metode dalam penelitian ini adalah deskriptif kualitatif. Penelitian kualitatif dilakukan dengan tidak mengutamakan angka, tetapi mengutamakan kedalaman apresiasi interaksi antar konsep yang dipelajari secara empiris dalam novel ini, memberikan pemahaman tentunya dalam menganalisis karya sastra dengan pendekatan yang digunakan adalah pendekatan pragmatis mengingat implikasi dari pembaca melalui berbagai kompetensi mereka. Dengan memperhatikan indikator karya sastra dan pembaca maka permasalahan yang dapat diselesaikan melalui pendekatan pragmatis, antara lain berbagai tanggapan masyarakat tertentu terhadap suatu karya sastra, baik sebagai pembaca tersurat maupun tersirat, baik dalam kerangka sinkronis maupun diakronis. Hasil penelitian menunjukkan bahwa gaya bahasa dalam novel Piano in the Glass Box karya Agnes Jessica sangat bervariasi dan kreatif. Novel Agnes Jessicas Piano in a Glass Box berjumlah 377 halaman. Total frekuensi penggunaan Gaya Bahasa adalah 98 unit. Dalam novel Piano di Kotak Kaca karya Agnes Jessicain ini terdapat empat kelompok gaya bahasa, yaitu gaya bahasa komparatif, yaitu perumpamaan, metafora, personifikasi, dan antitesis, gaya bahasa yang kontradiktif, yaitu hiperbola, litotes, ironi, oxymoron, dan zeugma.
\end{abstract}

Kata Kunci: Gaya Bahasa, Kotak Kaca, 


\section{INTRODUCTION}

Literature is a branch of art. Concerning society, literature is a mirror of life that can take advantage of the values that exist in society. Literature was born from the deep reflections of its creator about life. Literature is not only considered as an imaginative work of art but also considered as a form of creativity that is useful for the readers' intellectual consumption. Literature also contains an element of beauty that fosters a sense of pleasure, pleasure, is touched, attracts attention, and refreshes the feelings of the audience. (Iye, 2019).

The form of creation that is seen as the result of literary activities is first seen from the material side, namely in the form of language. A literary work is an attempt to record the contents of the literary soul by using language instruments. Literature is a recorded form of language that will be conveyed to others. The use of language in literature is different from the language in other activities, such as in everyday language use.

So, literature as a form of art creation uses language as a medium of delivery. The view that literary language is a unique language, as in poetry, prose, it is common to show the use of a special language, which is unique. Language in literary arts can be equated with paint in painting. Both are elements, materials, tools, facilities, which are processed into a work that contains more value than the material itself. Language is a means of expressing literature. Whatever the author says or otherwise interpreted by the reader, inevitably has to do with the language of Iye, R., \& Susiati, S. (2018).

Disclosure of language in literature reflects the attitudes and feelings of the author and is intended to influence the attitudes and feelings of the readers. For this reason, the form of expression of literary language must be effective and contain aesthetic characteristics as a work of art. The effectiveness of the expression of literary language can be obtained through the creativity of the author, namely how the author can deal with and utilize language as carefully as possible so that literary language appears with a different figure from nonliterary language. Therefore, the forms of language and literary expression are largely determined by the imagination and creativity of the author himself.

Creation in a literary work, an author uses language to produce an effect that explains what is valuable in the life that is told by the author. The form is in the form of simple sentences and expressions or language styles. Therefore, the quality of a literary story is determined by the placement and use of language styles or language styles.

Karim, A. B., \& Yusnan, M. (2020) also argue that language style in a general sense is the use of language as a medium of communication specifically, namely the use of language in style with the aim of expressive pronunciation. Language style includes all elements of language: intonation, sound, words, and sentences.

Meanwhile, Susiati 2020 said that language style is the use of figurative words and the right comparison to describe something intended to form the plastic of language. Language plastic is the author's creativity in creating literary inventions by suggesting the right choice of words to allow "energy" following the thoughts and feelings contained in work (Djojosuroso and Pelenkahu. 2003).

"Linguistic style is a technique of expressing language, the meaning of which does not show the literal meaning of the words that support it, but rather the added meaning, the implied meaning, so it is a style that deliberately makes use of speech by utilizing figurative language. (Endraswara, 2003) There is still a meaningful relationship between literal forms and class meanings, but the relationship is indirect, or at least it requires a reader interpretation. To understand the expressions of class language, special 
attention is needed, especially to grasp what message the author meant. (Nurgiyantoro, 2002: 297) ".

A language style is a form of rhetoric, namely the use of words in speaking and writing to convince or influence listeners and readers. The word rhetoric comes from the Greek rhetor which means orator or orator. In ancient Greece, rhetoric was an important part of an education and therefore various styles of language were very important and had to be mastered really by the Greeks and Romans who gave names to these various arts of persuasion (Surastina, 2009). Based on the Author, the style that is called according to the author's name is known based on the identifying characteristics used by the author or writer in his essay. A strong author can influence his contemporaries, or followers, to form a school. We know Chairil's style, Takdir's style, and so on.

Agnes Jessica's strengths in writing the novel Piano di Kotak Kaca lies in the aspect of the story which is presented with a coherent plot and clear conflicts so that it is not boring and interesting to follow. The language style that is straightforward and straightforward in describing an event makes the ideas he will convey in the story easy to understand. Based on the background description above, the writer can formulate a problem, namely how is the language style in Agnes Jessica's Piano Novel in the Glass Box?

\section{RESEARCH METHOD}

The type of research in this research is literature. Literature research is a theoretical description that underlies the study of the opinions of experts (Ratna, 2008: 56). The researcher will clearly describe the words, sentences, and paragraphs about the Language Style in the Piano Novel in the Glass Box by Agnes Jessica. The data referred to in this study are in the form of words, sentences, and paragraphs contained in the Language Style in the Piano Novel in the Glass Box by Agnes Jessica. The data source in this study is the written data text, namely Novel Piano in a Glass Box by Agnes Jessica, Publisher: PT Gramedia Pustaka Utama (Jakarta, 2007) Thickness: 384 pages.

This research is classified as a qualitative descriptive study. Therefore, the technique used to conclude this research data is the technique of reading and taking notes with the following steps: a) Reading the novel Piano in the Glass Box by Agnes Jessica, Publisher: PT Gramedia Pustaka Utama (Jakarta, 2007). b) After reading the next step, the identification and inventory phase of the problems found in the novel Piano in the Glass Box by Agnes Jessica will be carried out. c) Next, analyze the novel Piano in the Glass Box by Agnes Jessica and search for reinforcing data or references to strengthen or assist in the novel analysis process. After the data is collected, the next step is to analyze the data based on the principles of qualitative data analysis. In analyzing the data in this study, the approach used is pragmatic.

\section{RESULTS AND DISCUSSION}

In this study, the writer will describe the results of the research with the problem, namely the Language Style contained in the novel Kapas-Kapas di Langit by Pipiet Senja. The language styles to be analyzed in the novel are comparative styles consisting of: parable, metaphor, personification, allegory, and antithesis, then the language style of conflict which consists of hyperbole, litotes, irony, oxymoron, paronomasia, paralympic, and zeugma, then Style. Linkage Language consists of Metonomia, Alusio, Euphemism, Inference, and Gradi, then the repetitive language style consists of Alliteration, Antalacnasis, and Repetition.

\section{Comparative Language Style Parable}

The data of the parable in the Comparative Language Style contained in the Cotton- 
Cotton in the Sky consists of sixteen pieces. This can be seen as follows:

"Ada apa, Pa. Renny teriak-teriak memanggilku seperti kebakaran jenggot, ada apa?" seru wanita cantik itu terpogohpogoh menghampiri Haryanto. (Hal: 18)

In the above quote, the parable's Language Style is marked by the sentence Renny screams out for me like a beard fire. The meaning of the above language style about beard fire is the rush of emotion that someone does when he is pressed or there is an important information

Sheila menghapus air matanya yang seolah-olah berlomba-lomba keluar dari matanya. (Hal: 28)

In the above quote, the parable's Language Style which is marked with the sentence Sheila wiped her tears that seemed to be racing out of her eyes. The meaning of the Language Style above is crying sobbing.

Menurut Reza, nama itu tidak pantas untuk sebuah Wedsing Organizer yang lebih pantas dinamai 'Bridal Link', 'One Stop Marrige', atau ' Wedding Compass', dan bukan nama yang nggak nyambung yang artinya sepatu kaca. Tapi dengan berjalannya waktu, Reza mengakui keunikan The Glass Slipper yang ternyata banyak menarik pelanggan wanita yang ingin bahagia seperti Cinderella. (Hal: 251)

In the above quote, the parable's Language Style is marked with the sentence For Wenny he wants to create a world of Cinderella and her glass shoes. The sentence above explains that For Wenny she wants to create the world of Cinderella and her glass shoes, which means to look good, beautiful, and handsome.

\section{Metaphorical}

The metaphorical data in the Comparative Language Style contained in the Cotton-Cotton in the Sky consists of eight pieces. This can be seen as follows:
"Tidak bisa! Benda itu peninggalan mamaku, aku tak mungkin menukarnya walau dengan kalung emas yang kau pakai!" (Hal: 39)

In the quote above, the Metaphorical Language Style is marked with the sentence. The object is a legacy of my mother, I can't possibly exchange it even with the gold necklace you wear. This sentence is a figurative sentence which means that the object

Wenny yang penasaran ingin ikut melihat. Digesernya Tini yang bertubuh pendek dan tidak berminat sama sekali mengintip jendela. Tapi Tini tidak mau bergeser. Rupanya suara berisik mereka terdengar oleh anjing di rumah itu. Anjing itu menyalak. Salakannya terdengar semakin dekat. (Hal: 55)

In the quote from the sentence above, the Metaphorical Language Style is marked by the shift of Tini, who is short and has no interest in peeking at the window. The sentence is a figurative sentence which means that Tini is very short, this is a physical comparison, namely, Tini is not the same as her friends who have a tall body.

Satu jam kemudian mereka ditemukan Pak Teguh di belakang asrama. Api di lab kimia sudah berhasil dipadamkan. Untung api bisa dimatikan sebelum menyambar zat pembakar lain. Kalau tidak bisa-bisa sekolah kebakaran. Walau mereka kabur pelakunya dapat diketahui oleh guru. Pasalnya ada enam belas lilin dan bungkusan kue pukis di lantai serta coca cola dalam botol besar. Ketika di cek hanya Sheila yang berulang tahun hari ini, dan usianya genap enam belas tahun. (Hal: 61)

In the quote above, the Metaphorical Language Style is marked with the sentence "Fortunately, the fire can be turned off before grabbing other combustibles." This sentence is a figurative sentence which 
means that the fire can be put out quickly so that the fire does not grow.

Mereka inginnya diperhatikan, dipujinya, dan diberi servis yang baik. Bila melakukan ini pada mereka, naskah bagus mengalir deras dan uang pun akan mengalir deras ke pundi-pundi perusahaan. (Hal: 115)

In the quote above, the Metaphorical Language Style is marked with a good text flowing profusely and money will flow freely into the company's coffers. The sentence is a metaphorical sentence which is an object with another object and has a different word, namely profusely.

\section{Personification}

The personification data in the Comparative Language Style contained in Kapas-Kapas in the Sky consists of six pieces. This can be seen as follows:

Wajah Sheila memucat. Kalau belajar dengan wanita menyeramkan itu, lebih baik ia tak usah belajar piano. Dirinya yang tadi seperti melambung ke langit sekarang seperti terbanting ke tanah. (Hal: 29)

In the quote above, the Metaphorical Language Style is indicated by the sentence the sky is now slammed to the ground. The sentence is a personification sentence which is an embodiment that describes inanimate objects that can move to act like humans. The sky cannot be slammed against the ground.

Mata Sheila berkaca-kaca. Tak dipungkurinya hatinya terkadang rindu pada ayahnya bila ia membayangkan betapa ayahnya begitu mengasihinya. Waktu ayahnya mengajaknya berdua saja ke Taman Ria, atau ke pantai ancol bermain pasir. Atau waktu ayahnya membelikannya kembang api pulang dari bekerja, atau...... Banyak sekali hal-hal tiba-tiba teringat, yang membuat hatinya sangat sedih. (Hal: 155)
In the quote above, the Metaphorical Language Style is marked with the sentence when his father took him alone to Taman Ria, or Ancol beach playing with sand. The sentence is a personification sentence which is an embodiment that describes inanimate objects that can move to act like humans.

Mereka berdua sangat rapuh, dan sedikit saja tekanan akan membuat mereka meledak seperti popcorn di dalam panci tertutup. (Hal: 326)

In the above sentence, the Metaphorical Language Style is marked with the sentence. They are both very fragile, and a little pressure will make them explode like popcorn in a closed pot. The sentence is a personification sentence which is an embodiment that describes inanimate objects that can move to act like humans.

\section{The antithesis}

The Antithesis data in the Comparative Language Style contained in the Cotton-Cotton in the Sky consists of seven pieces. This can be seen as follows:

Mira memeluk Sheila dan menghirup keharuman rambut anaknya. Meskipun rambut Sheila tidak terlalu harum dan sedikit bercampur dengan bau matahari, Mira selalu senang memeluk anaknya, seolah-olah Sheila baru lahir kamarin sore. Ya, ini bayinya, kesayangannya. (Hal: 10)

In the quote above, the Antithesis Language Style is indicated by the sentence Sheila's hair is not too fragrant and is slightly mixed with the smell of the sun. The sentence is an antithesis sentence which is a combination of words that are mutually concurrent but have opposite meanings. As the quote above, Sheila's hair is not very fragrant but has mixed with the sun.

"Tidak bisa! Benda itu peninggalan mamaku, aku tak mungkin menukarnya walau dengan kalung emas yang kau pakai!" (Hal: 39) 
In the quote from the sentence above, the Antithesis Language Style is marked with the sentence. The object is a legacy of my mother, I can't possibly exchange it even with the gold necklace you wear. The sentence is an antithesis sentence which is a combination of words that are mutually concurrent but have opposite meanings.

"Langit cerah ya, kebetulan hari ini tidak hujan." ucap Sheila. Haryanto ikut melihat ke atas. Ia mengambil toples berisi biskuit dan menyodorkannya pada Sheila. "Biskuit kelapa?" Sheila menggeleng. "Seandainya aku bisa menjadi bintang itu, memancarkan cahayanya dari jauh dan membuat orangorang yang melihatnya ikut bahagia...." (Hal: 170)

In the above sentence quote, the Antithesis Language Style is marked with the sentence "Wish I could be that star, emit light from afar and make the people who see it happy too." The sentence is an antithesis sentence which is a combination of words that are mutually concurrent but have opposite meanings.

\section{Conflict Language Style Hyperbole}

The hyperbole data in the Conflict Language Style contained in the CottonCotton in the Sky consists of fifteen pieces. This can be seen as follows:

Suara-suara ribut seperti ini bagai mengimpit jiwanya sampai ia mau mati rasanya (Hal: 7)

In the quote, the sentence is a hyperbole language style, which is marked by a statement. Noises like this are squeezing his soul until he feels like dying. The sentence above contains the meaning of containing expressions that exacerbate the situation.

"Ada apa, Pa. Renny teriak-teriak memanggilku seperti kebakaran jenggot, ada apa?" seru wanita cantik itu terpogohpogoh menghampiri Haryanto. (Hal: 18)

92
In the quote, the sentence is a hyperbole language style, which is marked by the word Fire beard. The sentence above contains an expression that exacerbates the situation, the bloom of the beard means emotion with someone.

\section{Litotes}

The litotes data in the Conflict Language Style contained in the Cotton in the Sky consists of five pieces. This can be seen as follows:

Tertegun karena kata-kata kasar berusan, Sheila sadar ia cuma numpang tinggal di rumah ini, sampai kapan? Ayahnya bisa di penjara puluhan tahun lamanya, dan ia juga tidak mau tinggal bersama ayahnya kelak. Sheila teringat kata-kata polisi yang datang ke rumahnya. Ia mesti tinggal bersama seorang wali sampai punya KTP dan dianggap dewasa. Baik, aku mesti bersyukur di beri tempat di sini. Aku akan pergi dari sini (Hal: 21)

The quote from the sentence above contains the Litotes Language Style, which is that I must be grateful to be given a place here. I'll get outta here. The statement was meant to be condescending. Even though the house is very comfortable to live in.

"Tidak bisa! Benda itu peninggalan mamaku, aku tak mungkin menukarnya walau dengan kalung emas yang kau pakai!" (Hal: 39)

The quote from the sentence above contains the litotes language style, namely the object is a legacy of my mother, I can't possibly exchange it even with the gold necklace you wear. The statement is purported to be condescending because the piano is compared to gold.

"Sudahlah, Sheila. Sudahlah. Semua akan berlalu. Saat semua belalu, semua ini hanya tinggal kenangan, baik pahit maupun manis dalam kehidupanmu."(Hal: 174) 
The quote from the sentence above contains the litotes language style, namely Never mind. All will pass. When everything is past, all of this is just a memory. The statement was meant to be condescending.

\section{Irony}

The irony data in the Conflict Language Style contained in the CottonCotton in the Sky consists of five pieces. This can be seen as follows:

Selain airnya yang terlalu dingin sehingga ia malas mandi, selebihnya sih lumayan. Sebenarnya jauh lebih enak dari pada di rumah Haryanto. Di sini ia tak diperlakukan seperi pembantu. Kalau soal mencuci baju, toh itu bajunya sendiri. (Hal: 50)

The quote from the sentence above is a language style of irony because in the statement other than the water is too cold so he is lazy to take a shower. This sentence contains the meaning that even though there is water, he is lazy to take a shower.

Bila kamu ada dipersimpangan antara berbuat jahat dan baik, jangan sampai kamu terdesak berbuat jahat, apalagi membunuh. Emosi dapat menyebabkan....." (Hal: 69)

The quote from the sentence above is a language style of irony because in the statement if you have a distortion between doing evil and good, don't be pressured into doing evil. This sentence contains the intention of doing evil.

Anjing tak mungkin menghianati, anjing tak mungkin berdusta. Sedangkan manusia, tak ada satu pun yang bisa dipercayainya. Bram bangkit berdiri dan menuju kamarnya. (Hal: 126)

In the quote the sentence above is marked by the statement Dog cannot betray, dogs cannot lie. As for humans, there was nothing he could believe was an ironic style of language with a mocking intent.

\section{Oxymoron}

The oxymoronic data in the Conflict Language Style contained in the CottonCotton in the Sky consists of three pieces. This can be seen as follows:

Kenapa kau sama sekali tidak terlihat sedih melihat keluargamu tewas di tangan mereka?, tak puya perasaan sama sekali, tuduhannya pada shela semena-mena. (Hal: 21)

In the quote, the sentence above contains the oxymoronic style of language. The sentence why you don't look sad at all to see your family die in their hands has no feelings at all, his accusation to Sheila arbitrarily contains contradictory meanings. Thus, the words both time of joy and time of grief are the opposite in the same phrase.

Membawa dirinya dan nasibnya yang tak tentu, apakah esok masih hidup ataukah sama dengan yang lainnya, gagal mempertahankan hidupnya, alias mati. (Hal:.96)

In the quote, the sentence above contains the oxymoronic style of language. The sentence whether tomorrow is still alive or is it the same as the others, failing to survive, aka dying. So, it is opposite words in the same phrase.

\section{Zeugma}

The zeugma data in the Style of Conflict Language contained in the CottonCotton in the Sky consists of seven pieces. This can be seen as follows:

"Sheila, kamu tidur du kamar Renny saja. Ranjangnya kan ada dua, atas dan bawah. Yang bawah tidak pernah dipakai, kamu tidur disitu saja, ya?" ujar Haryanto. (Hal: 19)

The above-quoted sentence is marked with the words top and bottom. This word is a zeugma language style because it contains a combination of two words that contain conflicting semantic characteristics. 
Sheila mengendap-endap, Tini di belakangnya. Wenny paling belakang karena Tini maunya di tengah. Kalau benar-benar ada hantu yang kena belakang dan depan dulu, kata Tini. Mereka sudah melompati pagar dan tengah memasuki pekarangan. (Hal: 54)

In the quote, the sentence above is marked with the word back and front. is a zeugma style of language, because these words contain a combination of two words that contain conflicting semantic characteristics.

\section{CLOSING}

The various findings that the author can examine from this novel provide an understanding of course in analyzing literary works with an objective approach. This can be seen from the problem formulations that the writer can find after being analyzed and described following the data analysis in this study, it can be seen that the use of Language Styles in the novel Piano in the Glass Box by Agnes Jessica is very varied and creative. Agnes Jessicas' novel Piano in a Glass Box totals 377 pages. The total frequency of using Language Styles is 98 units.

In this novel Piano di Kotak Kaca by Agnes Jessicain, there are four groups of language styles, namely the comparative language style, namely parable, metaphor, personification, and antithesis, contradictory language styles, namely hyperbole, litotes, irony, oxymoron, and zeugma.

\section{BIBLIOGRAPHY}

Amri, M., Tahir, S. Z. A. B., \& Ahmad, S. (2017). The implementation of Islamic teaching in multiculturalism society: A case study at pesantren schools in Indonesia. Asian Social Science, 13(6), 125.

Amri, M., Afifuddin, A., \& Bin-Tahir, S. Z. (2018). Religious Pluralism of the Indonesian Traditional Islamic Education Institutions. The Journal of Social Sciences Research, 4(12), 446-450.
Bin Tahir, S. Z. (2017). Multilingual teaching and learning at Pesantren Schools in Indonesia. Asian EFL Journal, 89, 74-94.

Bin-Tahir, S. Z., Bugis, R., \& Tasiana, R. (2017). Intercultural Communication of a Multicultural Family in Buru Regency. Lingual: Journal of Language and Culture, 4(2), 8-8.

Bin-Tahir, S. Z., Atmowardoyo, H., Dollah, S., \& Rinantanti, Y. (2017). Multilingual learning program: pesantren students' perceptions of the multilingual simultaneous-sequential model. JELE (Journal Of English Language and Education), 3(2), 44-53.

Bin-Tahir, S. Z., Suriaman, A., Hanapi, H., Iye, R., \& Umanailo, M. C. B. (2020). Development of Buru Local Language Conversation Material Based on the CommunicativeInteractive Approach for Elementary School Students. Solid State Technology, 63(2s).

Bin-Tahir, S., Hanapi, H., Mufidah, N., Rahman, A., \& Tuharea, V. U. (2019). Revitalizing The Maluku Local Language In Multilingual Learning Model. INTERNATIONAL JOURNAL OF SCIENTIFIC \& TECHNOLOGY RESEARCH, 8(10).

Bin-Tahir, S. Z., Atmowardoyo, H., Dollah, S., Rinantanti, Y., \& Suriaman, A. (2018). MULTILINGUAL AND MONOMULTILINGUAL STUDENTS'PERFORMANCE IN ENGLISH SPEAKING. Journal of Advanced English Studies, 1(2), 32-38.

Bin-Tahir, S. Z., Hanapi Hanapi, I. H., \& Suriaman, A. (2020). Avoiding Maluku Local Languages Death Through Embedded Multilingual Learning Model: Menghindari Kematian Bahasa Daerah Maluku melalui Model Pembelajaran Embedded Multilingual. Uniqbu Journal of Social Sciences, 1(1), 53-60.

Bin-Tahir, S. Z. (2015). The Power of Love: The Role of Boyfriend in English Language Acquisition.

Bin-Tahir, S. Z., Suriaman, A., \& Rinantanti, Y. (2019). Designing English Syllabus for Multilingual Students at Pesantren Schools. Asian EFL Journal, 23(3.3), 5-27.

Bin-Tahir, S., Hanapi, H., Mufidah, N., Rahman, A., \& Tuharea, V. U. (2019). Revitalizing The Maluku Local Language In Multilingual Learning Model. INTERNATIONAL JOURNAL OF 
SCIENTIFIC \& TECHNOLOGY RESEARCH, 8(10).

Bin-Tahir, S. Z. (2020). The Role of Local Language in Intercultural Communication among Societies of Buru Island.

Bin-Tahir, S. Z., Suriaman, A., Hanapi, H., Iye, R., \& Umanailo, M. C. B. (2020). Development of Buru Local Language Conversation Material Based on the Communicative-Interactive Approach for Elementary School Students. Solid State Technology, 63(2s).

Bugis, R. (2018). SEATING ARRANGEMENT IN IMPROVING STUDENTS'SPEAKING SKILL AT IQRA BURU UNIVERSITY. Al-Lisan: Jurnal Bahasa (e-Journal), 3(1), 79-92.

Bugis, R., Malik, S., Kurniawan, R., Umanailo, M. C. B., \& Hehamahua, H. (2019). RONGO-RONGO DALAM PEMENUHAN KEBUTUHAN RUMAH TANGGA. JISPO Jurnal Ilmu Sosial dan Ilmu Politik, 9(2), 135-158.

Bugis, R., Tuharea, M. S., \& Akhmad, Z. (2021). Exploring EFL Teachers' Classroom Management Approaches and Students Responses to Male and Female Teachers. Al-Lisan: Jurnal Bahasa (eJournal), 6(1), 112-127.

Candrasari, R., Fadhillah, N., Praza, R., \& Desiariawati, N. (2018). An Analysis of Culture Value in Adat Bak Poe Teumeureuhom, Hukom Bak Syiah Kuala, qanun Bak Putro Phang, Reusam Bak Binatara. Indian Journal of Public Health Research \& Development, 9(12).

Djunaidi, F. G., Azwan, A. Y. T., Iye, R., \& bin Tahir, S. Z. Decks Range Gola Village Community Begun District Buton District North.

Fadhillah, N., Lubis, M. H., Sinar, T. S., \& Setia, E. (2019). Translation strategies used in Indonesian translation of Acehnese poem "Munajat Perempuan Sufi Aceh Pocut di Beutong.". International Journal of Innovation, Creativity and Change, 9(4), 172-182.

Khalsiah, R., Fadhillah, N., Praza, R., \& Desiariawati, N. (2018). An Analysis of Culture Value in Adat Bak Poe Teumeureuhom, Hukom Bak Syiah Kuala, qanun Bak Putro Phang, Reusam Bak Binatara. Indian Journal of Public Health, 9(12).
Lubis, M. H., \& Fadhillah, N. (2020). LOOKING FOR TRANSLATION OF MEANING OF WORDS QALA IN MATAN ARBA IN HADITH. Talent Development \& Excellence, 12(1).

Mufidah, N., Firdaus, U. Z., \& Tahir, S. Z. B. (2018). Model Pengayaan Tutor Bahasa: Studi pre-learning pada Shabahul Lughoh di Ma'had Sunan Ampel Al Aly. Jurnal AtTa'dib Vol, 13(2).

Marani, I. N., Subarkah, A., \& Wijayanto, A. (2020, December). The Use of Computer Mediated Communication (CMC) in Distance Learning During Covid-19 Pandemic: Pros and Cons. In 6th International Conference on Social and Political Sciences (ICOSAPS 2020) (pp. 95-102). Atlantis Press.

Nurlaelah, N., \& Sakkir, G. (2020). Model Pembelajaran Respons Verbal dalam Kemampuan Berbicara. Edumaspul: Jurnal Pendidikan, 4(1), 113-122.

Rinantanti, Y., Bin-Tahir, S. Z., \& Suriaman, A. (2019). The Impact of EFL Senior High School Teachers' Performance in Papua, Indonesia toward the Students' English Learning Achievement. Asian EFL Journal, 23(3.3), 431-447.

Sakkir, G. (2020). The Effectiveness of Pictures In Enhance Writing Skill of Senior High School Students. Interference: Journal of Language, Literature, and Linguistics, 1(1).

Susiati, S., Masniati, A., \& Iye, R. (2021). Kearifan Lokal Dalam Perilaku Sosial Remaja Di Desa Waimiting Kabupaten Buru. Sang Pencerah: Jurnal Ilmiah Universitas Muhammadiyah Buton, 7(1), 8-23.

Sofie, samsudiin, Iye, R., Tenriawali, A. Y., \& Susiati, S. (2021). IDEOLOGI PRANGGAPAN PAMFLET SOSIALISASI PELESTARIAN LINGKUNGAN DI KABUPATEN BURU. BAHTERA: Jurnal Pendidikan Bahasa Dan Sastra, 20(1), 7283. https://doi.org/10.21009/bahtera.201.07

Suriaman, A., Bin-Tahir, S. Z., \& Usman, S. (2019). Designing Web-Based English Listening Instruction: An Analysis of Indonesian University Student's Needs. Asian EFL Journl. Vol. 23 (3.3), 28-40.

Saidna Z, B. T., Haryanto, A., Syarifuddin, D., \& Yulini, R. (2017). Multilingual Instructional Model of Pesantren Schools in Indonesia. Journal of Language Teaching and Research, 8(6), 1210-1216. 
Sakkir, G., \& Dollah, S. (2019). Measuring students' writing skills using Facebook group application in EFL context. International Journal of Humanities and Innovation (IJHI), 2(3), 6974.

Tahir, S. Z. B., Atmowardoyo, H., \& Dollah, S. (2018). BELAJAR BERBICARA MULTIBAHASA UNTUK SANTRI PESANTREN. Yogyakarta, Deepublish.

TAHIR, S. Z. A. B. (2017). Pengembangan Materi Multibahasa untuk Siswa Pesantren (Doctoral dissertation, Pascasarjana).

Tahir, S. Z. B. (2015). Multilingual Teaching And Learning At Pesantren. 14 Asian EFL Journal Conference.

Tahir, S. Z. A. B. (2017). Pengembangan Materi Multibahasa untuk Siswa Pesantren (Unpublish Doctoral dissertation, Pascasarjana). Universitas Negeri Makassar.

Tahir, S. Z. B., \& Buru, D. U. I. (2012). Humor in "Bukan Empat Mata" Talk Show. Jurnal JUPITER, 5(4), 68-74.

Tuharea, V. U., Tahir, S. Z. B., Ami, I. S. O., \& Rahman, A. (2020). Buru Language Conservation Through Sustainable Mulok Learning In Buru Regency:(Konservasi Bahasa Buru melalui Pembelajaran Mulok Berkelanjutan di Kabupaten Buru). Uniqbu Journal of Social Sciences, 1(2), 49-55.

Umanailo, M. C. B., Bin-Tahir, S. Z., Mukaddar, M., Kubangun, H., Hamiru, H., Sangadji, M. F., ... \& Yusuf, S. (2018). Economics And Survival Moral Strategies Of The Upland Rice Farmers. In International Conference on Life, Innovation Change and Knowledge (Vol. 1, No. 1).

Wahyuningsih, T., Bugis, M., \& Bin-Tahir, S. Z. (2019). Analysis of the Inequality on Interregional and Inter-time Income Distribution in Indonesia. The Journal of Social Sciences Research, 5(1), 1-8.

Wargadinata, W., Maimunah, I., Tahir, S. Z. B., \& Umanailo, M. (2020). Arabic creative and participative learning: in search of a new way of language learning by "El Jidal Reborn" youth community in Malang. International Journal of Advanced Science and Technology, 2(8s), 4319-4332.

Wijayanto, A. (2021). BUNGA RAMPAI Kolaborasi Multidisiplin Ilmu Dalam Menghadapi Tantangan di Era New Normal.
Wijayanto, A. (2018). PENGARUH METODE GUIDED DISCOVERY, DAN METODE MOVEMENT EXPLORATION SERTA PERSEPSI KINESTETIK TERHADAP HASIL BELAJAR PUKULAN ATAS BULUTANGKIS PADA MAHASISWA IAIN TULUNGAGUNG. Halaman Olahraga Nusantara (Jurnal Ilmu Keolahragaan), 1(2), 160-176.

Wijayanto, A. (2018). Pengaruh Latihan Renang Teratur Dan Latihan Renang Tidak Teratur Terhadap Kadar Trigliserida Plasma Pada Rattus norvegicus. Biotropic The Journal of Tropical biology, 2(1), 2440.

Wijayanto, A., Hakim, A. A., \& Iffah, N. (2020). PENGARUH METODE PEMBELAJARAN EXPLORATION MOVEMENT DISCOVERY SERTA PERSEPSI KINESTETIK TERHADAP HASIL BELAJAR LAY UP BOLABASKET PADA MAHASISWA IAIN TULUNGAGUNG. JURNAL SEGAR, 9(1), 1-13.

Wijayanto, A., \& Susanto, S. (2018). Norma Komponen Pembibitan Olahraga Anak Madrasah Ibtidaiyah Usia 10 Sampai 12 Tahun Se-Kabupaten Tulungagung. JURNAL SEGAR,7(1), 110.

Wijayanto, A. (2018). PENDAMPINGAN PENGGUNAAN MOLASSES DALAM MEMPERCEPAT PENGOLAHAN DAN PEMANFAATAN FESES TERNAK UNTUK PEMBUATAN PUPUK ORGANIK. JPM PAMBUDI, 2(1), 1-12.

Wijayanto, A., \& Rusdi, R. (2017). PENDAMPINGAN KELOMPOK USAHA PENCACAHAN LIMBAH PLASTIK DI KABUPATEN MALANG. JPM PAMBUDI, 1(1), 11-11.

Wijayanto, A., \& Lani, A. (2017). OPTIMALISASI ALTERNATIF PRODUK SAYUR DAN PEMASARAN BERBASIS ON-LINE. JPM PAMBUDI, 1(1), 28-28.

Yusuf, M. (2021). BUNGA RAMPAI Integrasi Keilmuan Dalam Menghadapi New Normal Pada Masa Pandemi Covid-19. 
Wijayanto, A. (2021). Penerapan Adaptasi Kebiasaan Baru pada Era Pandemi Virus Corona 19 di Berbagai Sektor Pendidikan.

Asrifan, A., \& Wijayanto, A. (2021). Bunga Rampai Anak Bangsa INTEGRASI ILMU KEOLAHRAGAAN Dalam Preventif Pandemi COVID-19.

Wijayanto, A., \& Khurniawan, A. W. (2021). BUNGA RAMPAI Strategi Pembelajaran Pendidikan Jasmani Olahraga Dan Kesehatan Selama Pandemi Covid-19.

Wijayanto, A., Or, S., \& Kom, S. (2020). JAGA JARAK FISIK, JAGA KESEHATAN, JAGA KEBUGARAN UNTUK MENINGKATKAN IMUNITAS TUBUH DI TENGAH GEMPURAN COVID19. Dalam Preventif Pandemi, 1.

Yulismayanti, H., Iye, R., \& Susiati, S. Z. B. T. (2020). VARIATIVE METHOD IN IMPROVING STUDENT LEARNING MOTIVATION IN PANDEMIC COVID-19 SITUATIONS. Journal of Critical Reviews, 7(5), 1584-1595.

Yusriadi, Y., Bin-Tahir, S. Z., Farida, U., Sakkir, G., \& Akbar, Z. (2019). Community Perception in the Use of" Songkok Recca" Hats based on Social Stratification. Anthropos: Jurnal Antropologi Sosial dan Budaya (Journal of Social and Cultural Anthropology),5(1), 31-39.

Yusriadi, Y., bin Tahir, S. Z., Awaluddin, M., \& Misnawati, M. (2020). Pengentasan Kemiskinan melalui Socialpreneur. Wikrama Parahita: Jurnal Pengabdian Masyarakat, 4(2), 115-120.

Yusnan, M., Kamasiah, R. I., Karim, H., \& Bugis, R. (2020). Alih Kode dan Campur Kode pada Novel Badai Matahari Andalusia Karya Hary El-parsia: Transfer Code And Mix Code In Novels Badai Matahari Andalusia Karya Hary Elparsia. Uniqbu Journal of Social Sciences, 1(1), 1-12. 